\title{
Analysis of use of Methods and Quality Management Tools in a Group of Production Enterprises
}

\author{
Zbigniew Skuza \\ Czestochowa University of Technology, Poland
}

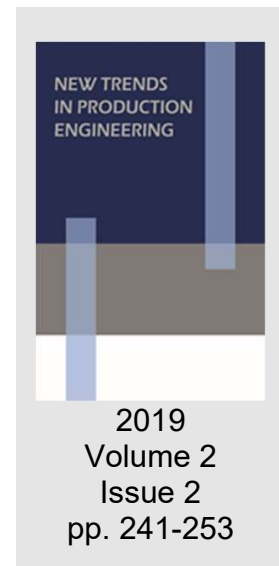

Date of submission to the Editor: 09/2019

Date of acceptance by the Editor: 11/2019

\section{INTRODUCTION}

Thirty years have passed since the socio-economic changes as a result of which a free market economy was introduced in Poland. Following this, the producer's market suddenly changed to a consumer's market in many segments in a short period of time. A variety of offered goods appeared, and the economic transformation affected all economic entities, causing fundamental changes in the way they function. Entrepreneurs operating in the conditions of market orientation began to notice such aspects of management that had been neglected or marginalized in the previously centrally controlled economic system. As the intensity of competition increased, there was a rapid development of departments dealing with marketing, logistics or human resources.

The changes did not bypass quality management either. Managers of domestic organizations quickly understood that quality must be treated as a necessary but not sufficient condition to achieve market success. The gradual easing of customs barriers, the accession treaty with the European Union and finally the membership in the community (2004) caused Polish companies to gradually begin to adopt the standards of Western countries. At the beginning of this road, one enterprise with the implemented ISO 9001 standard was registered in Poland in 1991, in 1995 the increase in certificates granted in this area was 130, but already in 2000 it amounted to 2075, and by 2009 it reached the maximum value of 12707 and 2017 it decreased to 11846 - Fig. 1. Against the background of EU countries (Fig. 2), Poland is ranked seventh in terms of the number of ISO 9001 certificates, but considering the number of inhabitants of a given member state, we are significantly below the EU average (Italy leads the way).

When analyzing data available on official websites of the International Organization for Standardization, it can be noted that the number of ISO 9001 certificates granted in most cases (countries) is subject to annual fluctuations with a slight downward trend. 


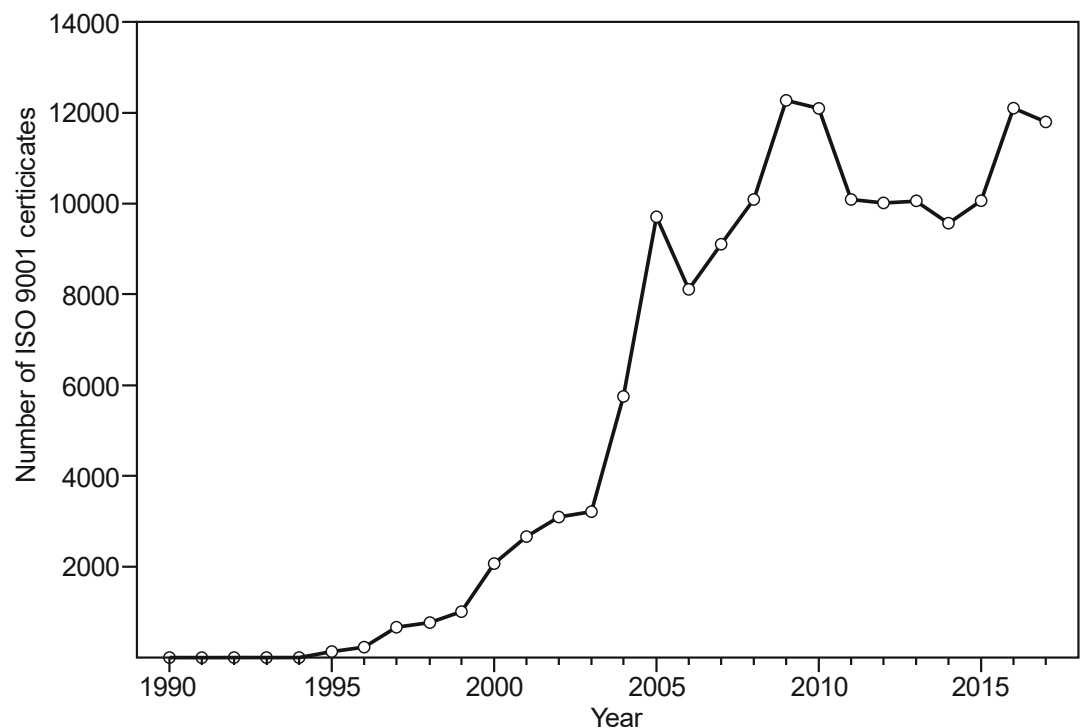

Source: (iso.org)

Fig. 1 Number of ISO 9001 certificates in Poland 1990-2017

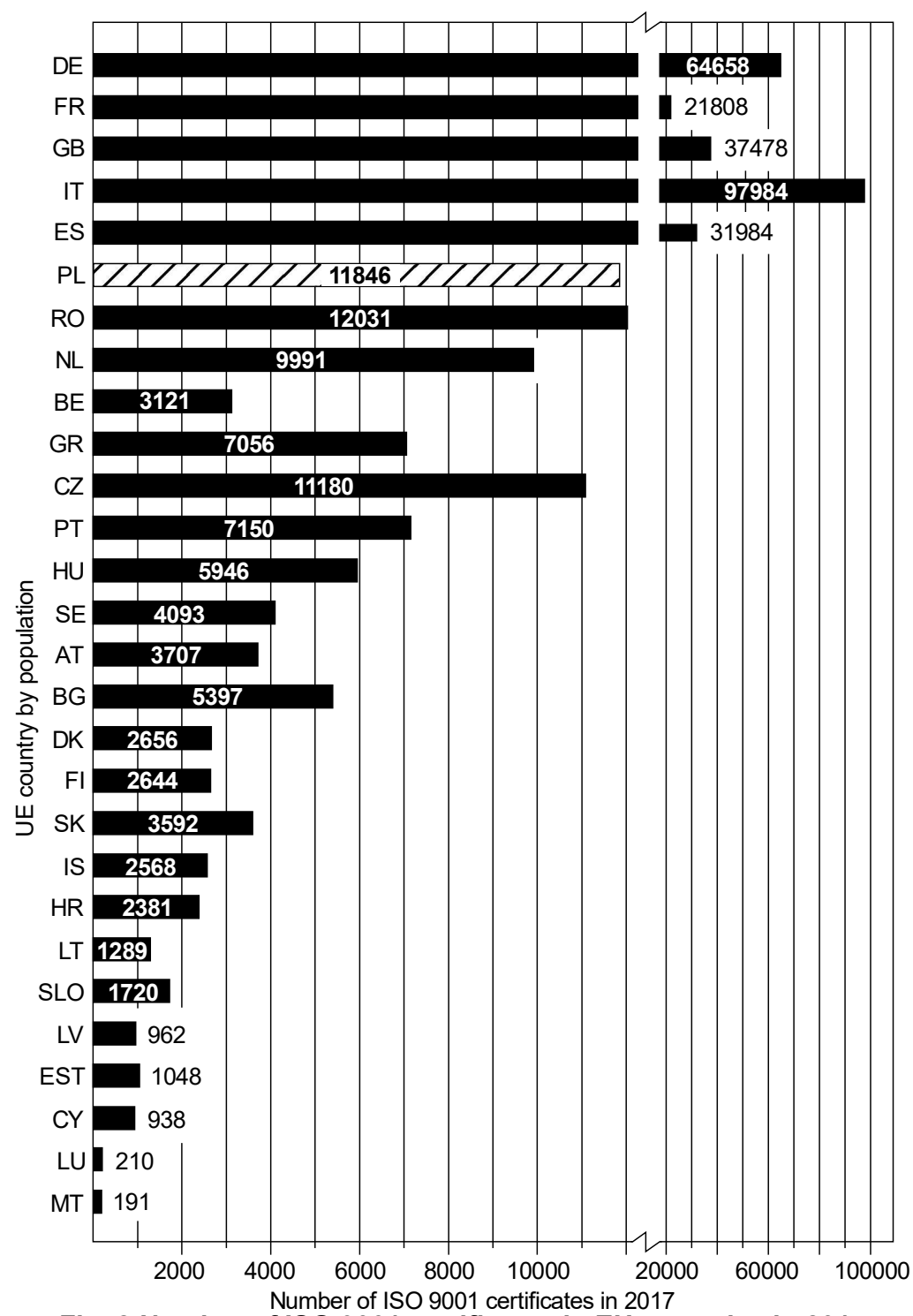

Fig. 2 Number of ISO 9001 certificates in EU countries in 2017

Source: (iso.org) 
According to the author of publication (Roszak, 2019; Andreeva, et al., 2018; Dahlgaard-Park et al., 2018), the reasons for this state of affairs (e.g. in Poland) should be seen in the following facts (Maurin et al., 2019):

- The ISO Committee has developed over 19,000 standards; entrepreneurs have noticed that industry standards contain identical requirements to ISO 9001 (Why implement two identical standards?);

- Price dictates in tender procedures (So why ISO?);

- Certification bodies acting as commercial law companies are focused on profit and not on verifying the actual state of affairs;

- ISO standards have lost their "freshness - attractiveness";

- Searching for other solutions, new products (e.g. Toyota production system, Motorola - Six Sigma, turquoise management) giving a competitive advantage.

This does not mean, however, that ISO has died. According to Gregory $\mathrm{H}$. Watson, former president of the American Society for Quality (Kałużny, 2018), these standards will continue to be the standard, the basis of quality on which all subsequent concepts can be developed.

The significant role of quality in modern business management is also recognized by the author of work (Roszak, 2019; Carnerud \& Backstrom, 2019). However, he notes that maintaining a quality system based on ISO standards cannot be reduced to maintaining a specific status quo that only guarantees meeting certain requirements. Organizations should primarily use this system to build their competitive advantage. In the ISO 9004 standard it is even emphasized that the organization's success is a result of the synergy of the processes of improvement, learning and implementing innovations.

\section{QUALITY MANAGEMENT METHODS, TECHNIQUES AND TOOLS}

In the subject literature there is currently no uniform general classification of methods and techniques of quality management. Many attempts have already been made to organize a wide range of available tools using different division criteria. However, there are still new proposals to systematize the available instruments. Most often, traditional and modern tools are listed, although sometimes this system is extended e.g. with statistical tools (Hamrol, 2005) or supporting tools (Szczepańska, 2009). Some authors (Czyżewski \& Potęga, 2007) make a division bearing in mind the differences between the management process and the improvement process or the specificity of individual phases of the Deming cycle (Łuczak \& Matuszak-Flejszman, 2007), while others also include in their classifications additional methods (Łańcucki et. al., 1995; Fraś et al., 2006) and quality management principles (Gawlik \& Kietbus, 2008). Currently, in the process of improving and managing quality, among others the following methods, techniques and tools can be used (Łuczak \& MatuszakFlejszman, 2007; Sahoo, 2019; Krajcsak, 2019; Beard-Gunter et al. 2019):

- Kaizen (work philosophy) - they are small but permanent improvements implemented in terms of the status quo on the principles of continuity (Debnath, 2019); 
- The principle of zero errors - a kind of philosophy and at the same time a technique of avoiding human mistakes while working;

- Eight disciplines 8D - a way to solve problems to improve the product and process (implemented in 8 stages);

- 5PPJ - a tool supporting the analysis and solving of problems related to the quality of products (five-stage quality improvement process);

- Failure mode and effects analysis (FMEA) - uses employees' experience to identify areas of potential problems and errors and stimulates actions to reduce these problems;

- Taguchi methods - used both to optimize a new product or process, and to improve existing ones. It comes down to solving three problems related to quality: estimating quality, raising the level of quality at optimal costs, controlling and keeping costs at an optimal level;

- Quality function deployment (QFD) - a specific system of product or service design based on the fullest consideration of customer needs (it translates customer requirements into the language of technical requirements for each product);

- $A B C D$ Method - used to rank (create a ranking of factor validity) a list of factors that cause a given problem;

- Pareto analysis - serves to give validity to the factors (causes) that cause the problem (used interchangeably with the ABCD method) (Chu, et al., 2019);

- Fishbone diagram - a graphic presentation of the analysis of mutual links of causes that trigger a specific problem;

- Is - Is Not Matrix - identifies where to start searching for the causes of a given phenomenon (while eliminating non-significant factors);

- 5S Practices - a method of creating order and optimizing the workplace (selection, systematics, cleaning, neatness, self-discipline);

- SERVQUAL method - is used to evaluate and measure the quality of services (Kumar et al., 2019);

- Poka-yoke - mistake-proofing - the purpose of this method is to eliminate or minimize human errors in manufacturing and management processes resulting from physical and physical imperfections;

- Flowcharting - the purpose of its construction is to present the activities in a given process in a specific order in terms of: logicality, order, efficiency, sufficiency;

- Critical to Quality - to find problems in the process by studying its flow diagram;

- Arrow diagram - is the development of a block diagram consisting in the fact that each action is assigned the responsibility and time to do it;

- Tree diagram - is an effective tool in the planning process;

- Why-Why Diagram - similar to the cause and effect diagram, with the fact that each subsequent statement is determined by asking the question "why?" (Bailie, 1985);

- Interrelationship diagram - allows one to obtain logical connections and dependencies of a set of factors influencing the analyzed issue. The purpose 
of its application is the far-reaching ordering of information (Zhang et al., 2019);

- Matrix Diagram - allows one to present the connections and dependencies between the tasks, activities, processes, proposed solutions of the problem, etc;

- Affinity diagram, also called the KJ method (Jiro Kawakita) - it serves to organize many data, ideas, opinions and facts relating to a wide problem or issue;

- Contingency diagram - identifies and illustrates what may fail in a plan, schedule or process, indicating ways to avoid these problems;

- Deployment flowchart - shows step by step the actions of people (or groups of people) in a given process;

- Workflow diagram - is a tool that graphically depicts the processes occurring in the process (flows);

- Top-down flowchart - used to show important elements of a process or project containing smaller stages;

- SIPOC diagram (supplier, input, process, output, customer) - is a tool used to identify all the elements of the process before starting its implementation in accordance with the adopted rules and agreed criteria;

- Requirements and measures tree - a method that allows one to present the relationships between clients, requirements and indicators defining a product or service;

- Requirements Traceability Matrix - a technique of gathering information about the requirements and presenting them in a boundary form;

- Importance-performance analysis - helps in organizing discussions with clients about their needs and receiving products and services of a given organization;

- Brainstorming (heuristic method) - it serves two purposes: it creates a wealth of ideas about the problem under consideration, and it improves the ability to cooperate in a group (Brainwriting - participants do not say but write their ideas on a piece of paper);

- Nominal group technique (NGT) - this is an ordered method of group brainstorming;

- Storyboard - a visual record of ideas;

- List reduction - helps carry out appropriate activities in order to find out the most valuable proposals from a long list of ideas;

- Multivoting - allows one to narrow down an extensive list of possibilities into a smaller set;

- Plus Minus Interesting (PMI) - organizes a discussion aimed at identifying the strengths and weaknesses of a given idea and opportunities related to its implementation;

- Survey - it is used to collect data about the knowledge and opinions of target groups of people;

- Impact analysis - a type of interview on the need to make changes (identification of bottlenecks in the production or service process); 
- Operational definitions - useful definitions of important terms and procedures in measuring or collecting data (remove the ambiguity of words or actions);

- Six Sigma - is a concept of comprehensive organizational improvement, consisting of continuous monitoring and control to eliminate and prevent various nonconformities in processes and resulting products. This concept introduces a measure of the level of the quality of the process that allows incomparable areas of the organization's activity to be assessed. This measure is DPMO (Defects per Million Opportunities). It defines the number of errors in relation to a million possibilities of committing it. The probability of this in the case of six sigma was set at 3.4 errors per million operations;

- Statistical process control (SPC) - is a set of methods and statistical techniques, among others: control charts, analytic sheets, histograms, correlation diagrams, multiple regression, cluster analysis, structural equation modeling and path analysis (SEPATH), experiential planning, neural networks, used on the assumption that the process proceeds according to normal distribution (Gaussian distribution). SPC aims to improve the workflow by reducing deviations;

- Control charts - are used to graphically monitor a process;

- Run chart - a tool very similar to control charts. A progress graph (no control lines or warning lines) shows the measurement results on the y-axis and the time the measurement was taken on the x-axis;

- Histogram - a graphic presentation of the studied process values or events;

- Check sheet - a tool for monitoring the process (Has the analyzed event taken place?, How many times has it happened?);

- Scatter diagram - a tool (graphic) that aids in the evaluation of a potential correlation between two variables;

- Data mining - the process of discovering significant relationships (correlations), patterns and trends by screening large amounts of data;

- Normal probability plot - enables the analysis team to determine if the data set takes the form of normal distribution;

- Box plot - is a tool supporting the process of analysis and interpretation of statistical data (e.g. various distributions);

- Stratification - a technique used in conjunction with other data analysis tools (classifies data from various sources in terms of their significance);

- Graphs - tools used to present data in a simple graphical form;

- Design of experiments (DOE) - methods whose purpose is to plan and optimize experiments oriented towards quality design;

- Process capability - an analysis allowing one to determine the possibility of receiving an output ensuring that the requirements of the process specifications and the determination of the expected number of nonconforming products are met;

- Performance Index - allows one to monitor the performance of the process taking into account many different parameters; 
- Measurement System Analysis (MSA) - is to ensure that the results of the conducted measurements can be applied to the procedures adopted by the organization for their use;

- Effective-Achievable Matrix - allows one to systematize possible solutions from a larger set of solutions;

- Analytic hierarchy process (AHP) - helps to make very difficult decisions when there are many alternative solutions or conflicting goals;

- Process Decision Program Chart (PDPC) - helps choose the most optimal way to achieve the intended goal;

- Theory of Constraints (TOC) - it is a tool in the practical aspect of making organizational decisions in situations involving restrictions;

- Force Field Analysis - a kind of simulation of the consequences of undertaking specific actions (forces - conducive and limiting the achievement of the chosen goal);

- Hoshin Kanari - used to plan, implement and evaluate change management;

- Benefits and barriers exercise (B \& BE) - an exercise that helps to recognize the organization's personal and organizational profits resulting from the proposed change, as well as indicate obstacles that may appear in its implementation;

- Define-Measure-Analyze-Design-Verify (DMADV) - helps to eliminate the differences between customer requirements regarding a product or process and what is being designed;

- Results Matrix - helps analyze the results of a project;

- Activity chart - schedules project tasks in the right order and indicates when each task must be performed;

- Balanced scorecard (BSC) - a method of planning and verifying the effectiveness in the management system, associating strategies and indicators with financial goals;

- Cost of quality (COQ) - analyzes the costs of quality of a detailed or comprehensive nature;

- Mission statement wordsmithing - this is a method of writing a declaration that contains the ideas of all the team members;

- Mission statement checklist - it is supposed to ensure that the enterprise's declaration (mission) is written properly so that all interested parties will understand what should be achieved and how it should be achieved;

- SMART goals - facilitates the ability to determine the organization's goals;

- Work breakdown structure (WBS) - this method is used to identify tasks that are necessary to achieve the intended goal;

- Control of team goals - indicates how general or how detailed the goal or scope of the activity is. It makes it easier for employees to understand team goals;

- ACORN test - is used to check the scope of defined tasks to ensure that the task is fully understood; 
- Just In Time (JIT) - a technique used in management consisting in the complete elimination of waste, by providing every production process with all the necessary elements at the required time and in the required quantity;

- Lean management - this is a concept that eliminates activities that do not add value to the product (Palacios Guillem, 2019);

- Benchmarking - a systematic process of comparing the characteristics of an organization with competitors or leading companies in a given industry, and copying proven designs;

- Business process reengineering (BPR) - is a fundamental rethinking and radical redesign of processes in the company leading to a breakthrough improvement;

- Business Process Management System (BPMS) - determines the ability to create, work, carry out, analyze and optimize business processes (defines virtually all the activities in the organization - from the production process to the circulation of invoices or the implementation of service requests).

\section{ANALYSIS OF THE USE OF QUALITY MANAGEMENT METHODS AND TOOLS}

Articles (Kafel \& Sikora, 2013; Zając \& Kudła, 2016; Gudanowska \& Olszewska, 2014) attempt to analyze the use of quality management methods and tools. The assessment was made on various groups differentiated in terms of the number of surveyed organizations as well as their re-classification.

In the first case (Kafel \& Sikora, 2013), a sample of 29 food industry companies from south-eastern Poland (number of employees: 11 - small, 13 - mediumsized, 5 - large). The collected data allowed the authors to state that 7 organizations do not use any methods or tools of quality management, 14 indicated self-assessment of the organization, 5 - SPC, 4 - Just in Time, 2 Kaizen and 2 - lean management. At the same time, only one tool for quality improvement was used in ten companies, seven in 2, fourteen in 3 and one in four. The specificity of the industry to which the analyzed entities belonged meant that most of them had certified quality management systems: ten organizations - ISO 9001, nine IFS Food Standard, seven BRC Global Standard for Food Safety, six HACCP (Codex Alimentarius), five ISO 22000.

In the second case (Zając \& Kudła, 2016), 20 manufacturing enterprises (dominated by the construction and automotive industries) located in the Podkarpackie Voivodship (number of employees: 1 - micro, 7 - small, 9 medium-sized, 3 - large) took part in the research. The author found that the most popular method among the surveyed companies is 5 Whys, another the $5 S$ method and statistical process control. The tools were dominated by process diagrams, control charts and brainstorming.

In the next analysis (Gudanowska \& Olszewska, 2014), 165 companies from the Podlaskie Voivodship were surveyed. The most frequently indicated techniques included the action plan, control sheet, SWOT analysis, 5S technique, block diagram and control charts. 
The surveys conducted at the Institute of Production Management of the Faculty of Production Engineering and Materials Technology at Czestochowa University of Technology are similar in character as in the cited cases. The elaborations presented in the further part of the paper concern only the information collected so far, as the commenced research work is still ongoing. At present, 51 enterprises have been evaluated (number of employees: 16 small enterprises, 28 medium-sized enterprises, 7 large enterprises - Fig. 3) located mainly in the province of Silesia and the Łódź Voivodship - Fig. 4.

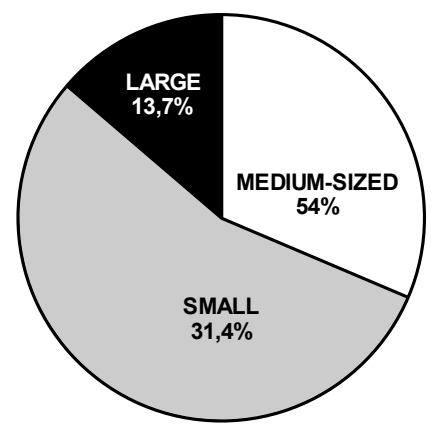

Fig. 3 Size of surveyed enterprises

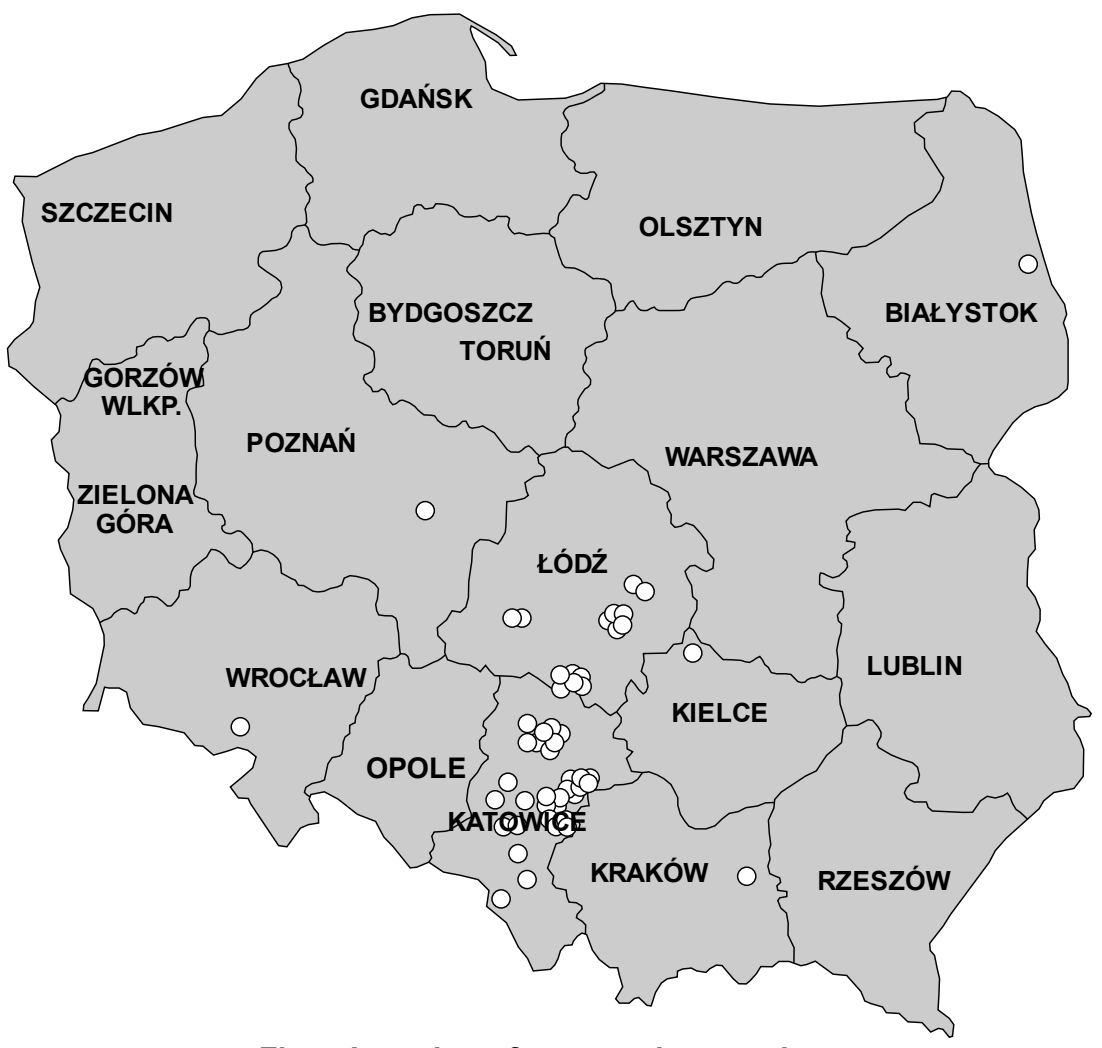

Fig. 4 Location of surveyed enterprises

The degree of use of various methods and techniques of quality management in the analyzed enterprises is shown in Fig. 5 . Only 7 organizations (13.7\%) declared that in their daily activities they do not use any tools or methods of quality management, 6 organizations $(11.7 \%)$ indicated one, and in eight cases $(15.7 \%)$, the permanent use of more than four techniques (maximum nine) was declared. 


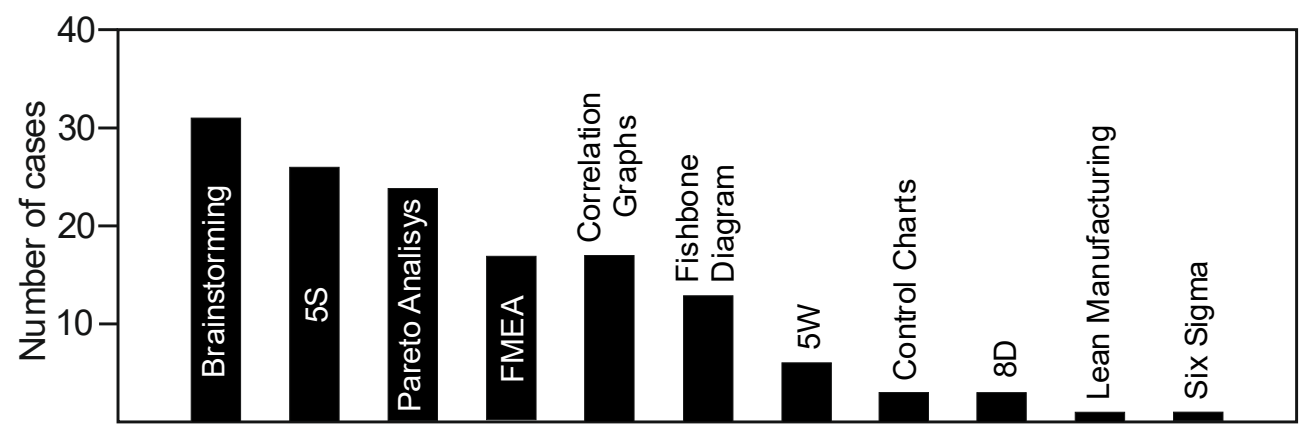

Methods and techniques

Fig. 5 Use of quality management methods and techniques in surveyed enterprises

In the discussed case, brainstorming (31 times), 5S Practices (26 times) and Pareto analysis (24 times) were among the most used instruments.

At the same time, 39 enterprises $(76.5 \%)$ have at least one management system confirmed by an independent certification body. Most of the 29 analyzed companies $(56.8 \%)$ have a minimum of 2 standardized management systems, 4 and more (maximum 5) are implemented in 8 of the examined facilities (15.6\%).

As shown in Fig. 6, the ISO 9000 standard is most popular - 35 cases, followed by ISO 14000 - 28 cases, ISO 18000 or PN-N-18000 - 28 cases, ISO 27000 9 cases, ISO $50000-6$ cases and others (e.g. IAFT 16949) - 11 cases.

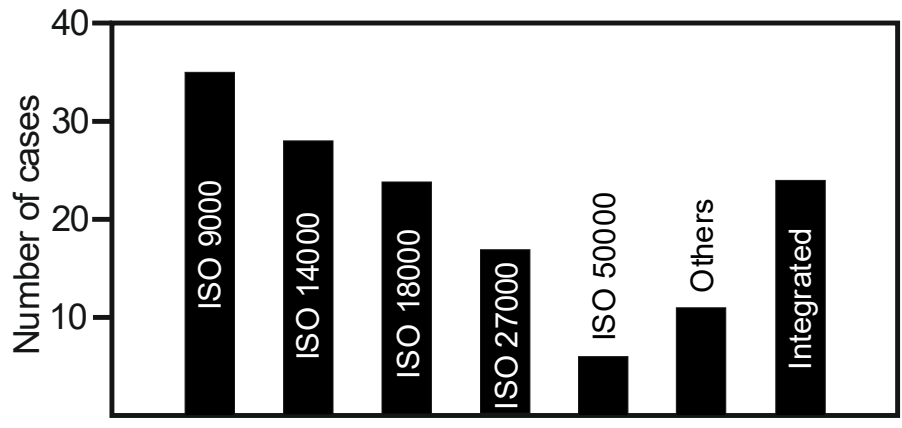

Norms

Fig. 6 Use of standardized quality management systems in surveyed enterprises

\section{SUMMARY}

Contemporary enterprises are facing another technological revolution. It is widely believed that such concepts as OI (open innovation), 5G, big data or Industry 4.0 will bring far-reaching changes. Possibly, access to much larger resources of information at any time, from anywhere will happen, which will translate into opportunities such as the economic production of short series of personalized products (so-called mass customization) (industry40.edu.pl). It is obvious that the progress of technology will also force changes in broadly understood management processes. The quality management system cannot remain on the side-lines and be a kind of "guardian of the present". On the one hand, it should be adapted to occurring changes (e.g. short series of products, a large variety of products, etc.), on the other hand it must be an effective tool in shaping the organization's management process, including continuous 
change management and related innovation implementation needs (Roszak, 2019).

In most cases, the analyzed enterprises used techniques and methods of quality management in their daily activities. Such proceedings were standard in organizations that had implemented a certified management system (e.g. ISO 9000 ) - usually this concerned large and medium-sized organizations. Both the organizations surveyed for the purposes of this work and cases cited from the literature indicate that the group of the most commonly used tools and methods is quite limited and in a sense it boils down to the most well-known ones. Such a situation may partly result from the specifics of a given industry (e.g. automotive - FMEA recommended) and the nature of production (mass production - possible application of SPC). In addition, the presentation of suggested responses in the questionnaire (in the form of examples, the most frequently used methods and techniques) could have influenced the choices made by the respondents. At the same time, in some cases, low awareness or insufficient substantive knowledge could have contributed to the belief among the respondents that specific techniques are implemented in the enterprise (e.g. treating ordinary discussion as brainstorming, etc.). Also noticeable is the minimal participation or lack of methods and tools aimed at implementing changes and innovations (Kaizen, QFD, benchmarking), which could increase the chances of achieving a longer-lasting competitive advantage.

All the remarks and observations noted at this stage of research will be included in subsequent analyses.

\section{REFERENCES}

Bailie, H. H. (1985). Organize your thinking with a why-why diagram. Quality Progress, 18(12), pp. 22-24.

Beard-Gunter, A., Ellis, D. G., Found, P. A. (2019). TQM, games design and the implications of integration in Industry 4.0 systems. International Journal of Quality and Service Sciences, 11(2), pp. 235-247.

Carnerud, D., Backstrom, I. (2019). Four decades of research on quality: summarising, Trendspotting and looking ahead. Total Quality Management \& Business Excellence, pp. 1-23. https://doi.org/10.1080/14783363.2019.1655397

Chu, J., Dickin, O., Nadarajah, S. (2019). A review of goodness of fit tests for Pareto distributions. Journal of Computational and Applied Mathematics, Vol. 361, pp. 1341.

Czyżewski, B. and Potęga, J. (2007). Narzędzia analizy i doskonalenia jakości. Poznań: Wielkopolski Klub Jakości FSNT NOT.

Dahlgaard-Park, Su. Mi., Reyes, L., Chen, C. (2018). The evolution and convergence of total quality management and management theories. Total Quality Management \& Business Excellence, 2- (9-10), pp. 1108-1128.

Debnath, R. M. (2019). Enhancing customer satisfaction using Kaizen: a case study of Imperial Tobacco Company (ITC). Journal of Advances in Management Research, 16(3), pp. 277-293.

Fraś, J., Gołębiowski, M. and Bielaw, A. (2006). Podstawy zarządzania jakością w przedsiębiorstwie. Szczecin: Uniwersytet Szczeciński, Rozprawy i Studia, T.(DCXCIX) 625.

Gawlik, J. and Kietbus, A. (2008). Metody i narzędzia w analizie jakości wyrobów. Kraków: Politechnika Krakowska im. Tadeusza Kościuszki. 
Gudanowska, A. E. and Olszewska, A. M. (2014). Techniki projakościowe wykorzystywane w podlaskich przedsiębiorstwach - wyniki badania wybranych jednostek. Zeszyty Naukowe Politechniki Śląskiej 2014 seria: Organizacja i Zarzadzanie z. $73 \mathrm{nr}$ kol. 1919.

Hamrol, A. (2005). Zarządzanie jakością z przykładami. Warszawa: Wydawnictwo Naukowe PWN.

http://industry40.edu.pl/czym-jest-przemysl-4-0/ - [Accessed 10 Jun. 2019] Andreeva, T., Zhulina, E., Popova, L., Yashina, M., Babynina, L., Yaksanova, N., Natsypaeva, E. (2018). Integration of strategic ang quality management in oil and gas companies of Russia. Quality - access to success, 19(163), pp. 81-84.

Kafel, P. and Sikora, T. (2013). Wykorzystanie metod i narzędzi zarządzania jakością w przedsiębiorstwach branży spożywczej. Żywność. Nauka. Technologia. Jakość, 1 (86), pp. 204-216.

Kałużny, M. (2018). Czy ISO umarło?. QUALITY - Magazyn dla praktyków, 7, pp. 8-9.

Krajcsak, Z. (2019). Leadership strategies for enhancing employee commitment in TQM. Journal of Management Development, 38(6), pp. 455-463.

Kumar, V., Hundal, B. S. (2019). Evaluating the service quality of solar product companies using SERVQUAL model. International Journal of Energy Sector Management, 13(3), pp. 670-693.

Łańcucki, J., Kowalska, D. and Łuczak, J. (1995). Zarządzanie jakością w przedsiębiorstwie. Bydgoszcz: Biblioteka menadżera i służby pracowniczej.

Łuczak, J. and Matuszak - Flejszman, A. (2007). Metody i techniki zarzadzania jakością. Kompendium wiedzy. Poznań: Quality Progres.

Maurin, A., Petit, A., Tilleul, P., Combeau, D. (2019). ISO 9001 certification of sterilization unit: transition to the 2015 version. Annales Pharmaceutiques Francaises, 77(5), pp. 363-373.

Palacios Guillem, M. (2019). New methodology developed for the integration of Lean Manufacturing; Kaizen and ISO 31000: 2009 based on ISO 9001:2015. 3C Empresa, 8(2), pp. 13-43.

Roszak, M. (2019). Innowacyjność a system zarządzania jakością. QUALITY Magazyn dla praktyków, 3, pp. 12-13.

Sahoo, S. (2019). Assessment of TPM practices on business performance: a multisector analysis. Journal of Quality in Maintenance Engineering, 25(3), pp. 412-434.

Szczepańska, K. (2009). Metody i techniki TQM. Warszawa: Oficyna Wydawnicza Politechniki Warszawskiej.

www.iso.org/the-iso-survey.html [Accessed 2 Jun. 2019]

Zając, S. and Kudła, B. (2016). Ocena wdrożenia oraz wykorzystania metod, narzędzi i technik zarządzania jakością $w$ przedsiębiorstwach w województwie podkarpackim. In: P. Lenik, ed., Prace naukowo-dydaktyczne, zeszyt 70, Krosno: Wydawnictwo Państwowej Wyższej Szkoły Zawodowej im. S. Pigonia, pp. 359383.

Zhang, Y., Hong, J., Li, X., Shi, V. (2019). The impacts of quality system integration and relationship quality on quality performance in supply chains: an empirical investigation in China. Emerging Markets Finance and Trade, https://doi.org/10.1080/1540496X.2019.1627196. 


\section{Abstract.}

The publication presents the results of research on the scope of practical use of available methods and tools of quality management by enterprises. The analysis was based on surveys conducted at the Production Management Institute of the Faculty of Production Engineering and Materials Technology of the Częstochowa University of Technology. The presented study applies only to the information collected so far as the research work commenced is still being continued. Currently, data (correctly completed questionnaires) has been collected from fifty one small, medium and large production companies located primarily in the Śląskie and Łódzkie region. Both the organizations surveyed for the needs of this project and the cases cited in the literature indicate that the group of the most commonly used tools and methods is quite limited and in a sense comes down to the most known. This situation may partly result from the specifics of the industry and the nature of production. In addition, providing questionnaire response suggestions (as examples, the most frequently used methods and techniques) may have influenced the choices made by the respondents. At the same time, in some cases, low awareness or insufficient substantive knowledge may have contributed to the belief among the respondents that the techniques are implemented in the enterprise while in reality these techniques have never been used. All remarks and observations noticed at this stage of the research will be taken into account in subsequent analyzes.

Keywords: quality management, methods, standards 